\title{
CHARACTERISTICS OF FINANCIAL POSITION OF RELIGIOUS ORGANIZATIONS IN RUSSIA AND ITALY: CONSTITUTIONAL LEGAL ASPECT
}

\author{
M. V. Michaylova*, I. A. Pibaev \\ Volgo-Vyatsky Institute (branch) of University named after O.E.Kutafin (MSAL), Kirov, \\ Lenin str. 99, Vyatsky State University, Kirov, Moskovskaya str., 36
}

Published online: 15 February 2017

\begin{abstract}
The article gives comparative analysis of approaches towards financing of religious organizations on the part of the state as one of the principles of a secular state. We give interpretation of the principle as of today. The authors attempt to research and define permissible limits of financial sovereignty of religious confessions. The article demonstrates considerable differences in the systems employed in Russia and in Italy. The authors suggest changing not only the mechanisms of providing financial support but also the procedure of rendering the accountancy.
\end{abstract}

Keywords: religion, Italy, Russia, secular state, religious associations, public funding, taxation.

\section{INTRODUCTION}

In the course of history our society developed along with the secularization of various spheres of life which resulted in entrenchment of a secular principle in constitutions. In the modern context of intensification of contradictions among global players and employing sophisticated methods of mind control of various segments of people, the problem of conflict prevention in the society is becoming pressing. The improvement of the efficiency of control and regulation of social processes that provide constant social development contemplates the use of experience of different nations in the development of approaches for the improvement of legal regulation of religious organizations financing on the part of the state.

Author Correspondence, e-mail: author@gmail.com

doi: http://dx.doi.org/10.4314/jfas.v8i2s.637 
The basic document in considering this problem is the Constitution of the Russian Federation which provides legal norms regulating financial activities of religious organizations. First of all, it defines the equality of all religious communities before the law, the principle stipulated in Article 14; secondly, Article 57 prescribes tax and fees liability; thirdly, Article 39, part 3 confirms recognition of charity in Russia.

In the world practice we can distinguish two main methods of state financing of religious organizations: direct and indirect. Various options of such assistance can be found in almost all countries regardless of the principles stipulated in their constitutions. However, even today in the European science of law state financing of religious confessions is one of the most "delicate and debatable problems of church law in the Western Europe" [1]. Let us research this delicate subject in the context of Russia and Italy.

\section{RESEARCH METHODS}

While researching the problem, we set up a methodological aim of the scientific inquiry - to find determinants affecting the character of financial position of religious organizations in the modern society, wherein the principle of secularism is fundamental. Deterministic approach was implemented by using the method of historical and logical unity, ascending from abstract notions to specific ones that gave an opportunity far and wide to research constitutional legal aspect of religious organizations financing through the example of Russia and Italy.

Comparative legal analysis assisted the revealing of similarities and differences in the long-standing legitimate forms of financial support of religious organizations in Russia and Italy. Without limitation to the phenomenological description of the situation in this sphere, on the basis of hermeneutic and axiological approaches, we suggest the ways of its improvement.

\section{CHARACTERISTICS OF FINANCIAL POSITION OF RELIGIOUS ORGANIZATIONS IN RUSSIA}

Before 2014, Russia had no mechanisms of direct financial assistance to religious organizations. On October 22, 2014 the federal law №315-FL "On introduction of amendments to the Federal law 'On Cultural Heritage Sites (historical and cultural monuments) of the peoples of Russia' and certain legislative acts of the Russian Federation" was adopted complementing the current Article 13 by clause 5 . This clause stipulated the capability (not duty) for the Russian Federation, its subjects and municipal units "out of their 
public funds to provide financial support to the arrangements aiming at preservation of the objects of cultural heritage owned by religious organizations $\langle\ldots\rangle$ ”.

It should be noted that earlier, renovation works on the objects of cultural heritage owned by the church were not financed by the state, and their municipal financing was not provided at all [2]. The state gave financial support only to religious objects of cultural heritage owned by the state or to those being in uncompensated use. Allocation of funds took place within the framework of the federal special-purpose program "Culture of Russia" and various regional programs.

We suppose that the change in financing the objects of cultural heritage will have a positive effect on their maintenance and operation as it is obvious that religious organizations seek to use religious objects for the intended purposes but the state should also care for the preservation of the objects which are historical monuments as well as those that have religious character.

Apart from a direct support, Russian legislators provided the measures of indirect assistance.

Firstly, a religious organization has to perform the duties vested to it by the state, among other things, the duty stipulated by Article 57 of the Constitution of the Russian Federation - to pay taxes in accordance with the legislation of the Russian Federation. However, taking into account their social significance, the state should provide certain tax benefits.

In accordance with tax legislation, benefits are granted in case of payment of valueadded tax, profit-tax for organizations, estate tax for organizations, land tax and in some cases when paying state duty. Shahov O.M. believes that the current tax policy in Russia in regard to religious confessions is a "sensible deviation from the principle of non-providing state financing for religious organizations separated from the state" [3]. Assets of religious nature are not the object of commerce and do not bring in proportional profits; so, for many religious organizations it is hard to pay taxes due to low income. As a result, religious organizations may be deprived of the opportunity to freely conduct religious worship.

Secondly, the measures of indirect assistance (that are no less important than tax benefits) include appropriation of funds through the mechanism of grants competitions.

On July 25, 2014, the President of the Russian Federation issued a decree №243 “On providing state support to non-commercial non-governmental organizations participating in the development of civil society institutions and realizing socially important projects in 2014". Under the decree, four non-commercial non-governmental organizations participating 
in the development of civil society institutions were granted subsidy from the federal budget for 2014, equal to 1,000,000,000 rubles. Before December 2014, competitive tenders on the projects were held that resulted in grant-making.

All-Russian Public Organization - the Society of Russia "Znanie" got 250 million rubles for 80 projects that aimed, among other things, at the support of the projects that have the objective to develop traditional spiritual values. Later, the Society of Russia "Znanie" held a grant competition resulting in many religious organizations getting substantial sums for various projects. It is important to stress that the recipients of the grants are representatives of different religious confessions.

Thirdly, due to enactment of the federal law from April 5, 2010 №40-FL, religious organizations got an opportunity to be recognized by socially orientated non-commercial organizations.

In the view of the above, we may say that in the Russian Federation there are direct and indirect mechanisms for the support of religious organizations.

\section{CHARACTERISTICS OF FINANCIAL POSITION OF RELIGIOUS ORGANIZATIONS IN ITALY}

For many years Italy had special historical connections between confessions and the state authority due to which we observe a curious scheme of financing of religious communities. The point at issue is the so-called practice of «tax-assignment».

In 1929 the signing of the Lateran Treaty led to legal settlement of reciprocal claims between Italy and the Holy See. From then onward, the state assumed the obligation to provide financial support to the Catholic Church. This mechanism was based on the recognition of economic loss suffered by the Church during the $19^{\text {th }}$ century as a result of numerous seizures of church property as well as the annexation of Papal States by the Kingdom of Italy in 1870.

The adoption of the Constitution of Italy in 1948 established the equality of people irrespective of their religion (article 3). De facto, state religion was abolished. But up to 1984, there was a system of state support of the Catholic Church introduced by the Lateran Treaty. Villa Madama Treaty, dated from February 18, 1984, availed new opportunities provided by the Codex Juris Canonici and fundamentally changed the system of state financing of the Catholic Church.

On May 20, 1985, a law № 222 "Provisions on organizations, church property in Italy and support of Catholic clergy serving in archdiocese" was adopted. This law brought into 
force the agreement on church efforts and property concluded between the State of Italy and the Catholic Church in the previous year. Two systems of financing of the Catholic Church as well as other confessions that had signed agreements with the state government were created.

Articles 47 and 48 of the above law established that from January 1, 1990 two new forms of economic support of the Church come into force. Thus the state stopped financing the Church directly.

At present, the first system is called "otto per mille" and concerns the quote of $0,8 \%$ of IRPEF revenue - income tax that is annually paid by all Italians making more than the minimum wage rate.

Filling in a tax return, a tax-payer may tick certain boxes thus transferring his money for a specified purpose:

a) to the state for implementing emergency measures against famine in the world and natural disasters, on rendering of assistance to refugees, for preservation of cultural property;

b) to the Catholic Church to support the clergy, religious public demands, community service in the interests of the national community or third world countries;

c) to one of the confessions reaching an agreement with the Italian government.

Thus, there were eleven beneficiaries (together with the Catholic Church) in 2014, as the Church of Jesus Christ of Latter-Day Saints (Mormon) refused to participate in the allocation of $0,8 \%$ of income tax. If one does not make choice, his quote is allocated among different recipients in proportion to the choice made by other taxpayers.

The specific feature of this system is the procedure of receiving the funds and their application. The system provides for considering taxpayers' viewpoint for three years ahead, i.e. religious organizations know in advance how much they will get and are able to plan their expenditure.

During the first three years (from 1990 to 1992) the state paid 210 million euros (up to 406 billion lire) to the Catholic Church annually. In fact, it constituted the sum paid to the General Assembly of the Italian Episcopal Conference in 1989 - the last year when state financing was in effect (399 billion lire for clergy and 7 billion lire for the construction and maintenance of churches). In 1993, the Church was paid such sum that was determined by the Catholic congregation in May of 1990 (303 million euros). In 1994, the amount of finance was equal to the sum allocated in 1991 and so forth. In 2013, the Catholic Church received 
$1,004,839,287$ euros because according to the data of the Ministry of Economy and Finance, in 2009, the percentage of decisions in favor of the Catholic Church was $82,01 \%$.

Annually, the General Assembly of the Italian Episcopal Conference has to allocate the funds into three parts: support of the clergy, expenditure on pastoral care, social service in the interests of the national community or third world countries.

Thus, in 2013, 382 million euros were allocated for the support of the clergy, 420,627 million euros - for pastoral care (maintenance of episcopacy, construction of churches, catechesis, etc.), 240 million euros - for charitable contributions. Besides, at the year-end a report on expenditure shall be submitted (in accordance with article 44-law № 222 from 20.05.1985). The agreements with other confessions contain similar and like provision.

The second type of financing concerns the option for private persons to reduce the tax base for the value of donation up to 1,032.91 euros intended to be used by the Clergy Support Catholic Central Institute (or the like institutions of other confessions). A particular procedure is prescribed by the Finance Minister's order. Though the procedure based on the choice of the people of Italy is quite transparent and the mechanism of its implementation is rather simple, nevertheless, there is certain criticism of this approach in Italy. The arguments are as follows:

Firstly, in the process of allocating the funds, the viewpoint of the people is not taken into account. Thus, according to the data of 2010, 1,149,289,469 euros were to be allocated among confessions. But only $43.5 \%$ of more than 30 million Italian taxpayers (who are due to provide tax return on the form №730 or «Uni.Co.») gave their preference to this or that confession. The rest $56.5 \%$ did not make any choice. From the $43.5 \%$ of those who made their choice, $36.98 \%$ decided in favor of the Catholic Church which got in total $85.01 \%$ of funds (due to the proportional system of allocation).

Secondly, the opponents of the economic support of religious organization consider that religious communities have to conduct their efforts on the basis of self-financing, i.e. at the expense of congregation, because only about $25 \%$ of the funds transferred to the Catholic Church go to charity, but the major part of the funds is spent on the maintenance of the Church itself. Thus, they believe that social benefits of church as a civil society institution are not evident.

Thirdly, an Italian association "Atheists and Agnostics-Rationalists Union" points out that the lack of agreements with other confessions operating on the territory of Italy, in particular, with the Moslem, the Orthodox of various jurisdictions does not give them a 
chance to participate in the receiving of the quote of $0.8 \%$, though the number of believers in these religions is sufficient (due to the migration processes).

In a certain way, the criticism of such system is reasonable. Moreover, it is difficult to blame legislators for unfairly considering the viewpoint of people: the problem resides in low activity of the people of Italia, in the lack of aspiration to express their viewpoint.

In a certain way, the criticism of such system is reasonable. Moreover, it is difficult to blame legislators for unfairly considering the viewpoint of people: the problem resides in low activity of the people of Italia, in the lack of aspiration to express their viewpoint.

In our opinion, the question of great importance in this situation is the lack of agreements between other confessions and the Italian government. However, in this case not everything depends on the government. The main problem resides in the absence of an Islamic association, which would represent the viewpoint of the majority of the Moslems in Italy. The fact that there are a few organizations claiming that they are representing the interests of the Moslems complicates the process of negotiations and coming to an agreement.

"There is no doubt, the current system of financing which follows the Spanish model is a step forward in comparison with the situation in Italy in this sphere before 1984", considers Silvio Ferrari. "In some way, it is even more preferable than the systems which are in force in other European countries. On the whole, its peculiar mechanisms are rather rigid and sometimes come into conflict with the freedom of religion" [4].

Besides the aforementioned direct methods of financing, there are additional forms of providing funds for religious organizations. In particular, this is the case with religious organizations, which have entered into an agreement with the Italian government: they are granted a remission of taxation on real estate in respect of the buildings of religious nature, they get $50 \%$ discount on corporate taxation; they have value-added tax allowance. Besides, many regional laws create favorable conditions for getting land parcels for the construction of houses of worship, and the law № 390 from 11.07.1986 provides for the assignment for use free of charge or the lease of state real property to religious organization.

Finally, it should be emphasized that the real estate of the Holy See located on the territory of Italy as well as other non-movable assets specified in Articles 13 and 14 of the Lateran Treaty are exempted from any taxation or other obligations owed to the state and other governmental organizations.

\section{SUMMARY}

To sum up, we would like to emphasize specific features of Russian and Italian systems of financial support of religious organizations. 
1. The current scheme of determining the extent and allocation of financial support to religious communities in Italy may be referred to as "operation of a pyramid principle". In this system we can find different levels of "selective engagement":

a) with a confession that for a number of historical reasons or the amount of believers has closer ties with the state, which results in its privileges in the financial sphere (Catholic Church);

b) with confessions that through public agreements have access to the quote of $0.8 \%$ from income tax and tax benefits;

c) with religious organizations conducting their activities in the form of common associations. They have no access to financing except for very limited methods.

From Ingrid Pistolesi's point of view, there exists a real risk that the difference in relationships with religious organizations may exceed permissible "healthy limits" and defy the basic principles of the system of state-confessional relationships (freedom of religion, non-discrimination, autonomy of organizations and equality of religions) [5].

2. In the Russian Federation there are direct and indirect measures of state support for all religious organizations. Exception to this rule applies where state support is provided for reconditioning of architectural monuments of the so-called "non-traditional" religious organizations. But this is hardly discrimination based on religion. This is due to the objective cause - there are no religious buildings (historical and cultural monuments) owned by such associations as seventh-Day Adventist church, Jehovah's Witnesses, etc. on the territory of the Russian Federation.

In spite of key distinctions in the above systems, we can find things in common for Russian and Italian models of financial support of religious organizations.

1. Russian Federation and Italian government agencies do not find any conflict between financial support of religious organizations from the state budget and the constitutional principle of secularism.

2. In the Russian Federation and in Italy religious organizations are provided with a wide range of tax benefits on payment of property tax, land tax, value-added tax. Moreover, the citizens of the Russian Federation and Italy are entitled to the reduction of taxation base in computation of income tax for the value of donations to religious organizations. But it stands to mention that such mechanism is scarcely employed in Russia. 


\section{CONCLUSION}

Thus, the comparative analysis of religious organizations financing in Russia and Italy demonstrates a number of similarities and differences between these systems. On the one hand, Italy has a system of supervision and control over financial support of confessions which is far beyond such system in Russia. On the other hand, it is worth mentioning that in the context of resent trends in Russia to increase indirect state support, the citizens (primarily, the believers themselves) practically lack any information awareness on the size and nature of religious confessions' expenses. The situation may be remedied by the improving legal regulation of both - the mechanism of providing financial support and the procedure of accountancy.

\section{ACKNOWLEDGEMENT}

The article is published with funding from awards "Talents cooperation" held by the University of Talents (Kazan).

\section{REFERENCE}

[1] S.Ferrari, I.C.Iban . Diritto e religione in Europa occidentale [Law and religion in Western Europe]. II Mulino. Bologna. 1997. Re-hatting. Agafonova A.A. Budgetary financing of religious organizations activities: comparative law research // State authority and local selfgoverning. №3. 2012.

[2] Right for justice. Interview with ihumenia Ksenia (Chernegoya) // Moscow Patriarchy's Journal. №1. 2015. P. 74-80.

[3] Shahov O.M. Legal basis for religious organizations' activities in the Russian Federation $-2^{\text {nd }}$ edition add. - M.: Publishing House of Sretensky Monastery, 2013.

[4] Religion and the secular State: the Italian case Alessandro Ferrari - Silvio Ferrari. 19952010 The Cardozo Institute 2010 edition: Vol. 16 (2010) - 1. The Fall Issue Italian National Reports to Washington 2010.

[5] Ingrid Pistolesi. I diversi modelli di finanziamento pubblico: uno sguardo d'insieme // Stato, Chiese e pluralismo confessionale №34. 2012.

\section{How to cite this article:}

Michaylova M V, Pibaev I A. Characteristics of financial position of religious organizations in russia and italy: constitutional legal aspect. J. Fundam. Appl. Sci., 2017, 9(1S), 32-40. 